\title{
The aminoglycoside antibiotic gentamicin is able to alter metabolic activity and morphology of MDCK-C11 cells: a cell model of intercalated cells
}

\author{
A.G.G. Coutinho ${ }^{1}$, S.M.P. Biscaia ${ }^{2}$, R. Fernandez ${ }^{1}$ and A.L. Tararthuch ${ }^{1}$ \\ ${ }^{1}$ Departamento de Fisiologia, Setor de Ciências Biológicas, Universidade Federal do Paraná, Curitiba, PR, Brasil \\ ${ }^{2}$ Departamento de Biologia Celular, Setor de Ciências Biológicas, Universidade Federal do Paraná, Curitiba, PR, Brasil
}

\begin{abstract}
It is well known that the aminoglycoside antibiotic gentamicin is capable of causing damage to kidney cells. Given the known involvement of $\mathrm{Ca}^{2+}$ in the nephrotoxic action of gentamicin, the purpose of this study was to establish a relationship between the concentration of intracellular $\mathrm{Ca}^{2+}\left(\left[\mathrm{Ca}^{2+}\right]_{\mathrm{i}}\right)$ and cellular cytotoxicity using MDCK-C11 cells, a clone that has several properties that resemble those of intercalated cells of the distal nephron. Changes in $\left[\mathrm{Ca}^{2+}\right]_{\mathrm{i}}$ was determined using fluorescence microscopy. Cell viability was evaluated by the neutral red method, and cell cytotoxicity by the MTT method. The $\left[\mathrm{Ca}^{2+}\right]_{i}$ gradually increased when cells were exposed to $0.1 \mathrm{mM}$ gentamicin for 10,20 , and 30 min. The presence of extracellular $\mathrm{Ca}^{2+}$ was found to be necessary to stimulate the increase in $\left[\mathrm{Ca}^{2+}\right]_{i}$ induced by gentamicin, since this stimulus disappeared by using $1.8 \mathrm{mM}$ EGTA (a $\mathrm{Ca}^{2+}$ chelator). Morphological changes were observed with scanning electron microscopy in epithelial cells exposed to the antibiotic. Furthermore, with the MTT method, a decrease in metabolic activity induced by gentamicin was observed, which indicates a cytotoxic effect. In conclusion, gentamicin was able to alter $\left[\mathrm{Ca}^{2+}\right]_{\mathrm{i}}$, change the morphology of MDCK-C11 cells, and promote cytotoxicity.
\end{abstract}

Key words: Gentamicin; $\left[\mathrm{Ca}^{2+}\right]_{i}$; MDCK-C11 cells; Cytotoxicity

\section{Introduction}

Gentamicin is an aminoglycoside antibiotic that has a broad spectrum of action against gram-negative bacterial infections and it is more recommended in severe cases (1). Since their development in 1940, aminoglycosides are preferably used in antimicrobial therapy. Gentamicin was discovered in 1963 and is still widely used, despite the availability of other aminoglycosides. Gentamicin remains popular because it is a low-cost, quite effective antibiotic, demonstrating low antimicrobial resistance (2). However, its use is restricted because of the development of ototoxicity and nephrotoxicity. Many studies were designed to reveal the underlying mechanism of its ototoxic and nephrotoxic effects. Currently, gentamicin-induced nephrotoxicity occurs in about 10 to $20 \%$ of treatments, and the progression to acute renal failure typically manifests after 5-7 days of treatment (3). In patients treated for more than 14 days, nephrotoxicity appears in about $50 \%$ of them, resulting in increased morbidity during and after treatment (4).

The proximal tubule is the first nephron segment that undergoes structural and histological changes caused by gentamicin and it is the major site of drug accumulation.
Gentamicin leads to the loss of brush border integrity and evident apoptosis and necrosis of proximal tubular cells (5). Accumulation of gentamicin in proximal tubule cells is due to the existence of an apical membrane endocytic complex involving the proteins megalin and cubilin (6). This endocytic receptor complex transports cationic molecules present in the tubular ultrafiltrate into the cells. Once inside the cells, gentamicin alters the function of various organelles. In addition to its toxic effects exerted through endocytosis, gentamicin is able to activate a calciumsensing receptor (CaSR) present in the apical membrane of proximal tubular cells, which has been associated with tubular cell death (3). CaSR agonists such as gadolinium and gentamicin activate phospholipase $\mathrm{C}$ in proximal tubular cells, resulting in the formation of inositol 1,4,5-trisphosphate and consequent $\mathrm{Ca}^{2+}$ release from intracellular stores (7). Recent studies have pointed to a central role of $\mathrm{Ca}^{2+}$ in the regulation of programmed cell death $(3,8)$.

There are few findings about the effect of aminoglycosides on distal kidney cells. Some of these studies determined endocytosis-independent mechanisms by which

Correspondence: A.L. Tararthuch: <analucia@ufpr.br>

Received March 9, 2018 | Accepted July 4, 2018 
gentamicin appears to directly cross the plasmatic membrane into the cytoplasm with the participation of membrane receptors such as the non-selective cation receptor TRPV $(9,10)$. It is well established that MDCK-C11 cells, a recently cloned subtype of Madin-Darby canine kidney cells akin to intercalated cells of the collecting duct, also have TRPV and CaSR receptors (9-13). However, the effect caused by gentamicin in these cells is not yet well understood. Understanding the cellular mechanisms by which the nephrotoxic aminoglycoside gentamicin activates membrane receptors and induces cellular cytotoxicity will enable future identification of aminoglycoside-sensitive targets and potential uptake blockers (14).

Given the known involvement of $\mathrm{Ca}^{2+}$ in the nephrotoxic action of gentamicin in proximal tubules, the purpose of this study was to establish a relationship between the concentration of intracellular $\mathrm{Ca}^{2+}\left(\left[\mathrm{Ca}^{2+}\right]_{i}\right)$ and cellular cytotoxicity, using MDCK-C11 cells, a clone that has several properties that resemble those of intercalated cells of the distal nephron.

\section{Material and Methods}

\section{Cell culture}

A subtype (clone) of MDCK cells denominated C11 (MDCK-C11), obtained from Dr. H. Oberleithner (Department of Physiology, University of Münster, Germany), was cultured in MEM (Gibco, USA), supplemented with $10 \%$ fetal bovine serum, $100 \mathrm{IU} / \mathrm{mL}$ penicillin, $10 \mathrm{mg} / \mathrm{mL}$ streptomycin, and $2 \mathrm{~g} / \mathrm{L} \mathrm{NaHCO}_{3}$. Cells were grown at $37^{\circ} \mathrm{C}(\mathrm{pH}$ 7.4 ) in a humidified $95 \%$ air and $5 \% \mathrm{CO}_{2}$ incubator (Shel Lab, USA). These cells were used from passages 75 to 90 .

\section{Intracellular $\mathrm{Ca}^{2+}$ measurements}

Qualitative changes in $\left[\mathrm{Ca}^{2+}\right]_{i}$ cell cultures were monitored for FLUO-4 fluorescent dye intensity emission. The excitation spectrum for this fluorescent marker is $480 \mathrm{~nm}$, whereas the fluorescence was measured at $520 \mathrm{~nm}$ every 1 second. The data are reported in arbitrary units of fluorescence (AUF). The resulting changes in fluorescence intensity during the experiments are reported as percentages relative to the fluorescence intensity at baseline (recording period with control solution: $135 \mathrm{mM} \mathrm{NaCl}$, $5 \mathrm{mM} \mathrm{KCl}, 1 \mathrm{mM} \mathrm{NaH}_{2} \mathrm{PO}_{4}, 1 \mathrm{mM} \mathrm{Na}_{2} \mathrm{SO}_{4}, 1.8 \mathrm{mM} \mathrm{CaCl}_{2}$, $10 \mathrm{mM}$ HEPES, $1 \mathrm{mM} \mathrm{MgCl} 2,10 \mathrm{mM}$ glucose). Cells grown to confluence on glass coverslips were incubated for $20 \mathrm{~min}$ with $10 \mu \mathrm{M}$ FLUO-4 (Molecular Probes, USA). After this, the glass coverslips were rinsed and placed into a thermoregulated chamber $\left(37^{\circ} \mathrm{C}\right)$ assembled on an inverted epifluorescense microscope (Axio Observer Z1, Carl Zeiss, Germany). Areas of interest containing MDCKC11 cells were identified at $20 \times$ magnification using the software AxioVision 4.8.1. Following a stabilization period with the control solution, the cell monolayer was exposed for 10 , 20 , and $30 \mathrm{~min}$ to a control solution containing $0.1 \mathrm{mM}$ gentamicin sulfate (Santa Cruz Biotechnology, USA) with a recording period of about $1 \mathrm{~min}$. Effects of the CaSR agonist $0.3 \mathrm{mM} \mathrm{Gd}^{3+}$, the calcium chelating agent $1.8 \mathrm{mM}$ EGTA (ethylene glycol-bis( $\beta$-aminoethyl ether)-N,N, $\mathrm{N}^{\prime}, \mathrm{N}^{\prime}$ tetraacetic acid; Amresco, USA), and 50 mM BAPTA (Santa Cruz Biotechnology) were evaluated under the same conditions compared to the effects of gentamicin.

\section{Analysis of cell viability and cell cytotoxicity}

Cell viability was evaluated by the method of neutral red, performed according to the protocols $(15,16)$. This method evaluates the cell ability for endocytosis by the uptake of the dye neutral red, by fluid phase. Cell cytotoxicity was evaluated by the MTT method (thiazolyl blue tetrazolium bromide, M5655, Sigma, USA), according to protocols previously described (16-18). The MDCK C11 cells were maintained in 96-well plates containing $0.1 \mathrm{mM}$ gentamicin sulfate for $30 \mathrm{~min}, 1,3,24$, and $48 \mathrm{~h}$. These plates were subjected to reading absorbance $(540 \mathrm{~nm}$ for neutral red and 550 for MTT) in a microplate reader (Biotek, EPOCH, USA.

\section{Morphological analysis}

MDCK C11 cells were seeded onto sterile 13-mm round cover slips plated in 24-well plates. After different times of treatment, cells were washed 4 times in $0.1 \mathrm{M}$ cacodylate buffer, $\mathrm{pH} 7.4$ at $4^{\circ} \mathrm{C}$. Next, the cells were fixed in Karnovski solution $(2.0 \%$ glutaraldehyde, $4 \%$ paraformaldehyde,

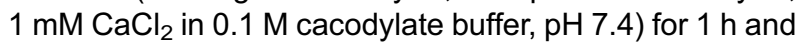
washed 3 times in cacodylate buffer. Then they were postfixed $(1 \%$ osmium tetroxide in sodium cacodylate buffer $0.1 \mathrm{M}, \mathrm{pH} 7.4$ ) for $1 \mathrm{~h}$ at room temperature and washed again in $0.15 \mathrm{M}$ cacodylate buffer, $\mathrm{pH}$ 7.4. The MDCK-C11 cells were then dehydrated in increasing concentrations of ethanol (Merck, Germany) $(30,50,70,90$, and twice $100 \%$ ) for a period of $10 \mathrm{~min}$ at each concentration. Finally, the cells were subjected to critical point in CPD 030 equipment, gold-coated in the SCD 030 equipment (Balzers, USA) and were analyzed in an LV scanning electron microscope (JEOL JSM 6360, USA) at UFPR Electron Microscopy Center.

\section{Statistical analysis}

Statistical analysis was performed using the GraphPad InStat 3.10 (GraphPad Software, USA). Data are reported as means $\pm S D$. In all data of $\left[\mathrm{Ca}^{2+}\right]_{i}$, measurements are reported as number of areas/number of assays. For analyzes between two groups, Student's $t$-test for paired samples was used. For analysis of more than two groups, we performed one-way ANOVA, followed by the StudentNewman-Keuls contrast test. Differences were considered significant if $\mathrm{P}<0.05$.

\section{Results}

\section{Effects of gentamicin on $\left[\mathrm{Ca}^{2+}\right]_{i}$}

Incubation of MDCK-C11 cells monolayers with $0.1 \mathrm{mM}$ gentamicin sulfate determined a significant increase of 
$\left[\mathrm{Ca}^{2+}\right]_{i}$ over time as observed in the representative recording shown in Figure 1. When MDCK-C11 cells monolayers were incubated for $10 \mathrm{~min}$, intracellular calcium increased from 100 to $117.3 \pm 23.7 \%(P<0.05)$. This increase reached $130.3 \pm 27.3 \%$ after $20 \mathrm{~min}$ and was sustained after $30 \mathrm{~min}$, where the difference from baseline recording was $138.1 \pm 32.9 \%$ (Figure 2). When the cells were incubated with $0.3 \mathrm{mM} \mathrm{Gd}^{3+}$, a CaSR agonist, the cytosolic ionized calcium increased to $107.9 \pm 19.6 \%$ after $10 \mathrm{~min}, 111.9 \pm$ $9.3 \%$ after $20 \mathrm{~min}$, and $116.1 \pm 8.0 \%$ after $30 \mathrm{~min}$. These values were significantly lower than those observed with gentamicin, as shown in Figure 2. The mechanisms for the increase of $\left[\mathrm{Ca}^{2+}\right]_{i}$ observed might be an influx of extracellular $\mathrm{Ca}^{2+}$ or activation of intracellular signaling pathways that promote release of calcium from the endoplasmic reticulum. In the absence of extracellular calcium

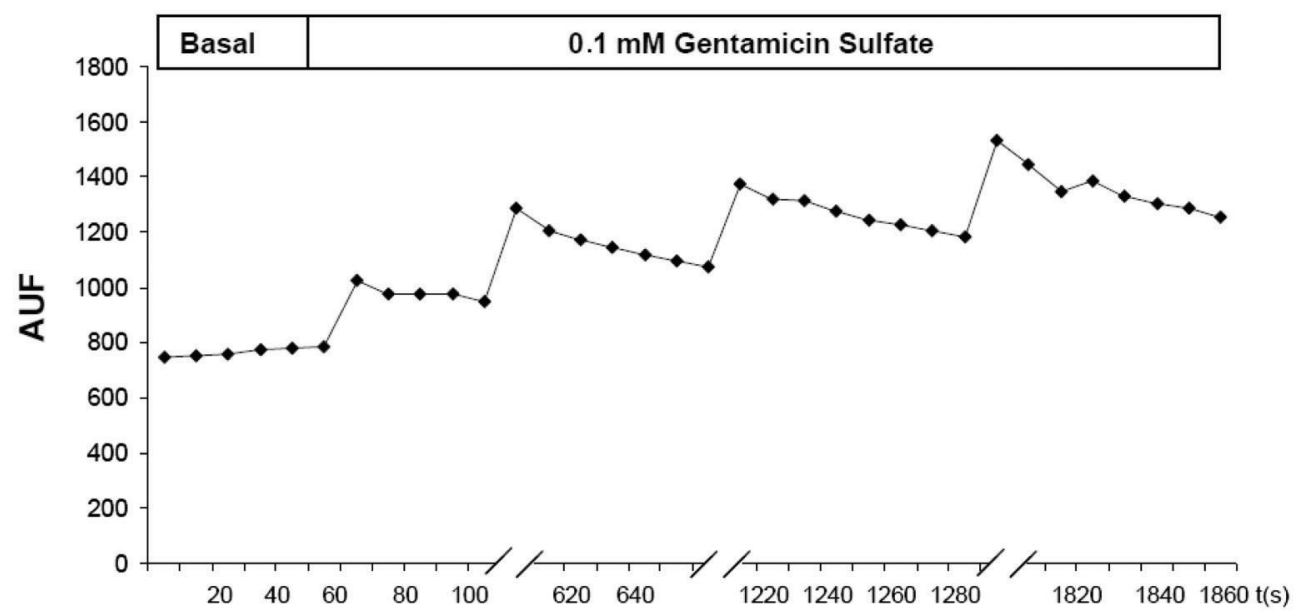

Figure 1. Representative recording corresponding to variations in $\left[\mathrm{Ca}^{2+}\right]_{\mathrm{i}}$. After a basal period, cells were exposed to $0.1 \mathrm{mM}$ gentamicin sulfate. At each pause of $10 \mathrm{~min}$, new excitation of the fluorophore was recorded, completing 30 min of gentamicin incubation. AUF: arbitrary units of fluorescence.

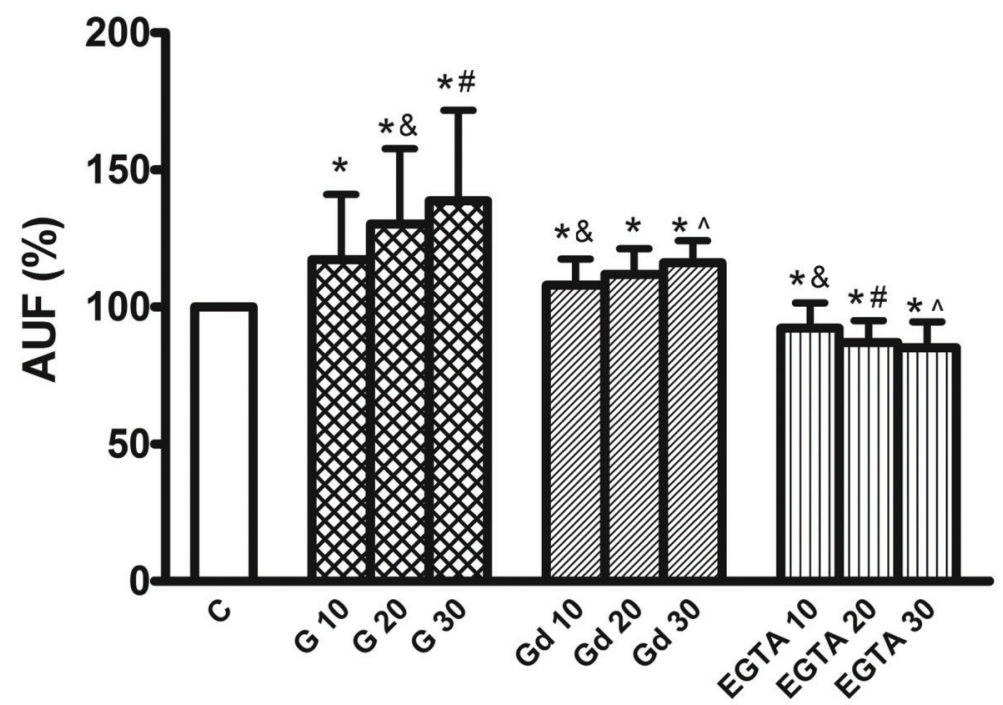

Figure 2. Mean values $\pm S D$ of percentage change in fluorescence (AUF), which indicates changes in $\left[\mathrm{Ca}^{2+}\right]_{i}$ compared to a hypothetical average $(C=$ control $100 \%)$. G $10(n=39 / 7), G 20(n=45 / 8)$, and $G 30(n=44 / 8)$ correspond to the $\left[\mathrm{Ca}^{2+}\right]_{i}$ change in cells incubated with $0.1 \mathrm{mM}$ gentamicin sulfate for 10,20 , and $30 \mathrm{~min}$. Gd $10(n=25 / 5), \mathrm{Gd} 20(\mathrm{n}=25 / 5)$, and $\mathrm{Gd} 30(\mathrm{n}=25 / 5)$ correspond to the [Ca $\left.{ }^{2+}\right]_{\mathrm{i}}$ change in cells incubated with $0.3 \mathrm{mM}$ gadolinium, without the addition of gentamicin. EGTA $10(n=14 / 7)$, EGTA 20 ( $n=6 / 3$ ), and EGTA $30(n=6 / 3)$ indicate the $\left[\mathrm{Ca}^{2+}\right]_{i}$ variations obtained in the presence of EGTA solution containing $0.1 \mathrm{mM}$ gentamicin sulfate. ${ }^{*} P<0.001$ compared to $\mathrm{C}$; ${ }^{\circledR} \mathrm{P}<0.02$ compared to $\mathrm{G} 10$; ${ }^{\#} \mathrm{P}<0.002$ compared to $\mathrm{G} 20$; ${ }^{\mathrm{P}}<0.002$ compared to $\mathrm{G} 30$ (ANOVA). AUF (arbitrary units of fluorescence). 
(from the addition of $1.8 \mathrm{mM}$ EGTA to medium containing gentamicin), the $\left[\mathrm{Ca}^{2+}\right]_{i}$ was significantly lower than control values at all exposure times (Figure 2). After incubation of MDCK-C11 cells for 10 min with the gentamicin solution containing $50 \mathrm{mM}$ BAPTA, an intracellular calcium chelator, the $\left[\mathrm{Ca}^{2+}\right]_{\mathrm{i}}$ decreased to near baseline values $(96.18 \pm 1.03 \%)$.

\section{Cell viability and cellular cytotoxicity}

MDCK-C11 cells viability was determined by the neutral red method, which evaluates the cell endocytic ability by measuring the absorbance of the dye. In these experiments, we evaluated changes in endocytosis capacity of the cells by exposing them to $0.1 \mathrm{mM}$ gentamicin at different times: $30 \mathrm{~min}, 1,3,24$, and $48 \mathrm{~h}$ (Figure 3). No significant difference was found between treated and control groups.

Using the MTT method, it was determined if gentamicin addition to MDCK-C11 cells may cause some toxic effect. From the measurement of the formazan crystals absorbance, cell viability associated with cytotoxicity in MDCK C11 cells was evaluated (Figure 4). When the cells were maintained for $48 \mathrm{~h}$ with gentamicin, the absorbance of the formazan crystals was significantly lower $(0.76 \pm$ $0.14, n=13)$ than that observed in cells maintained in control situation $(1.33 \pm 0.21, n=12)$, which indicated a reduction in their metabolic activity. A tendency of reduction in metabolic activity was also observed with $24 \mathrm{~h}$ of gentamicin exposure, but without statistical significance.

\section{Scanning electron microscopy}

The ultrastructural analysis of the cells by scanning electron microscopy demonstrated that monolayers exposed to control solution ( 3 and $24 \mathrm{~h}$ ) and those treated with gentamicin for $3 \mathrm{~h}$ showed that cells adhered well to substrate (Figure 5A, B, and C). Only when the cells were treated with gentamicin for $24 \mathrm{~h}$ were they loosened in a monolayer substrate (Figure $5 \mathrm{D}$ ). After treatment, these cells did not lose intercellular adhesion, but lost adhesion to substrate. Figure 6 shows an epithelium structure change just after $1 \mathrm{~h}$ of gentamicin treatment (Figure 6A, B, and C). Some colonies have cells with a more protruding aspect. Furthermore, over the entire cell culture, the presence of fibrillar material deposited can be observed, which does not appear in longer periods of gentamicin exposure.

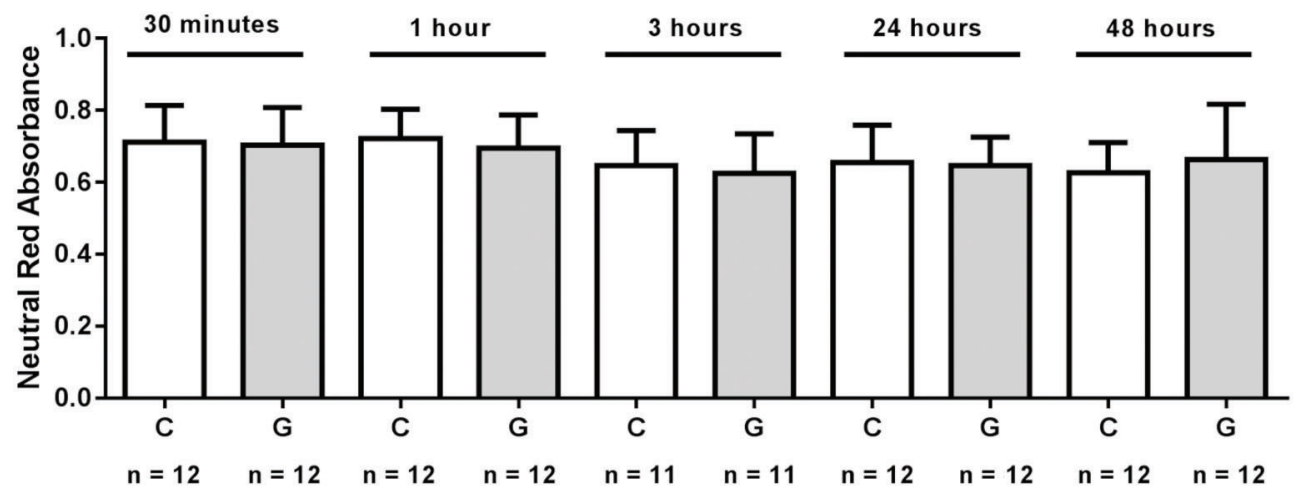

Figure 3. Neutral red absorbance by MDCK-C11 cells exposed to $0.1 \mathrm{mM}$ gentamicin sulfate $(\mathrm{G})$ compared to control $(C)(P>0.05$, Student's $t$-test for paired samples).

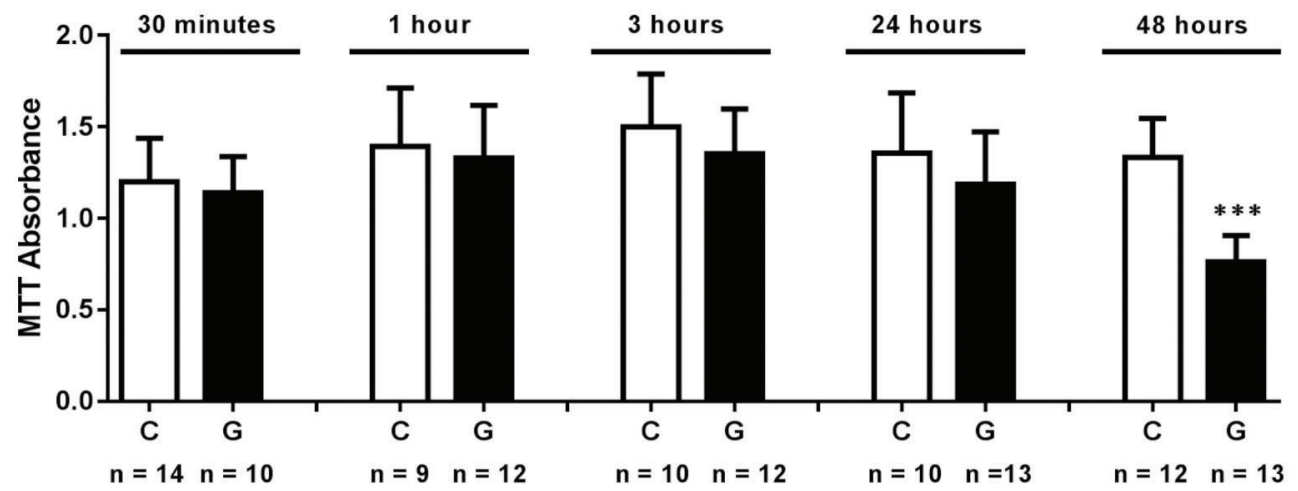

Figure 4. MTT absorbance by MDCK-C11 cells exposed to $0.1 \mathrm{mM}$ gentamicin sulfate. ${ }^{* \star *} \mathrm{P}<0.0001$ compared to control (C) (Student's $t$-test for paired samples). 

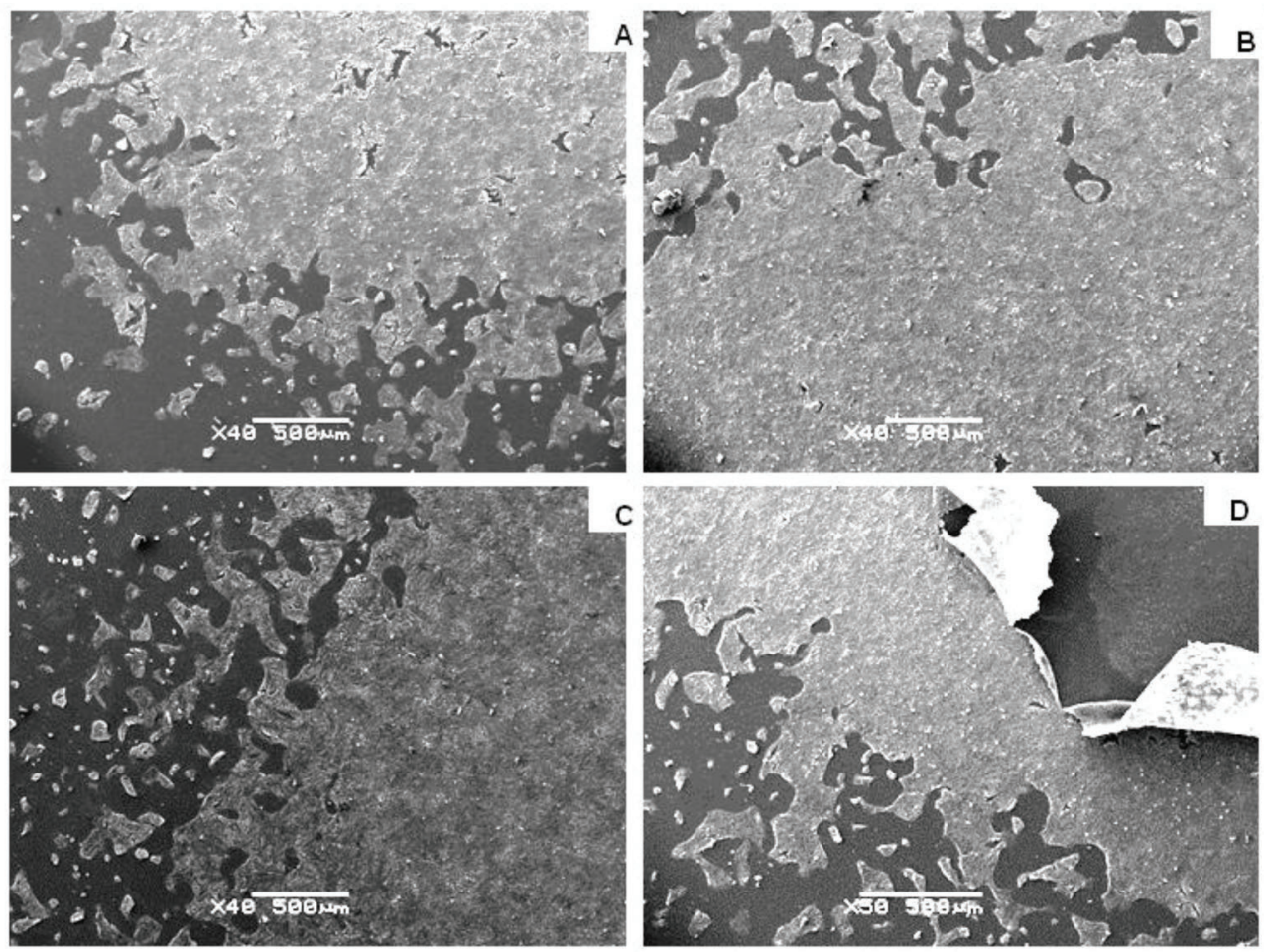

Figure 5. Ultrastructural analysis of MDCK-C11 cells by scanning electron microscopy. A: cells exposed to control solution for $3 \mathrm{~h}$ and $B$ : for $24 \mathrm{~h}$. $C$ : cells exposed to $0.1 \mathrm{mM}$ gentamicin solution for $3 \mathrm{~h}$ and $D$ : for $24 \mathrm{~h}$. Magnification bars: $500 \mu \mathrm{m}$.
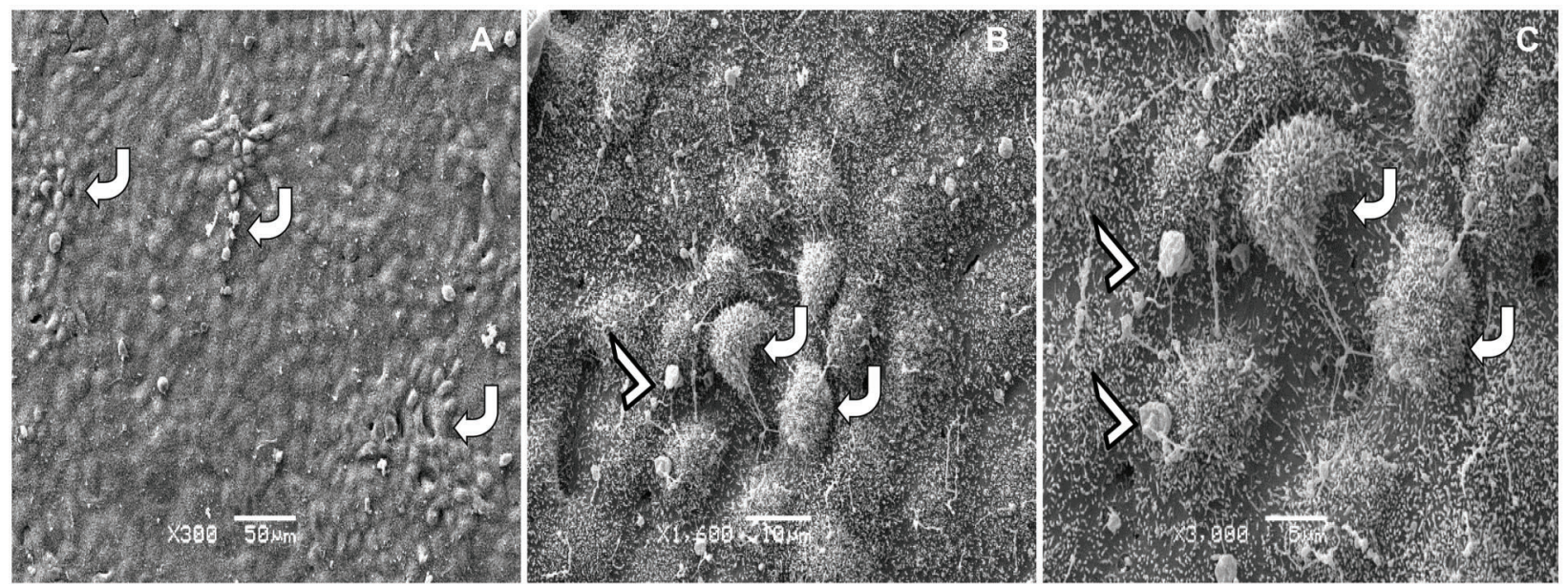

Figure 6. Ultrastructural analysis of MDCK-C11 cells by scanning electron microscopy. Panels $A$, $B$, and $C$ : cells exposed to $0.1 \mathrm{mM}$ gentamicin solution for $1 \mathrm{~h}$. Magnification: $A, \times 300,50 \mu \mathrm{m} ; B, \times 1600,10 \mu \mathrm{m} ; C: \times 3000,5 \mu \mathrm{m}$. Curved arrows: cell colonies that have a more protruding aspect. Arrow head: fibrillar material.

\section{Discussion}

Like gadolinium, neomycin, and tobramycin, gentamicin is also known as an agonist of CaSR $(7,19)$. Stimulation of CaSR activates phospholipase $\mathrm{C}$, resulting in the production of diacylglycerol and inositol 1,4,5-trisphosphate, the latter of which releases $\mathrm{Ca}^{2+}$ from the endoplasmic reticulum. In this study, MDCK C11 cells incubated for 10 min with $0.1 \mathrm{mM}$ gentamicin sulfate showed an increase in the intracellular $\mathrm{Ca}^{2+}$ level $\left(\left[\mathrm{Ca}^{2+}\right]_{\mathrm{i}}\right)$ that was higher 
than that obtained with gadolinium. This finding indicated that gentamicin would have a more pronounced effect on the activation of CaSR. Moreover, in the presence of BAPTA, there was no change in the $\left[\mathrm{Ca}^{2+}\right]_{i}$ level, even in the presence of gentamicin, because this drug is able to chelate all cytoplasmic $\mathrm{Ca}^{2+}$. An increase in the $\left[\mathrm{Ca}^{2+}\right]_{i}$ level greater than $30 \%$ may be responsible for triggering the toxic effect of this aminoglycoside on MDCK C11 cells. This effect does not depend on the endocytic pathway, but occurs by stimulation of $\mathrm{Ca}^{2+}$ per $\mathrm{Ca}^{2+}$, because in the absence of extracellular $\mathrm{Ca}^{2+}(\mathrm{EGTA})$, the $\left[\mathrm{Ca}^{2+}\right]_{\mathrm{i}}$ level remained at the basal level.

In this study, we also evaluated the viability of MDCKC11 cells exposed to gentamicin. Cells exposed to the antibiotic gentamicin showed no change in the uptake of neutral red dye, indicating that the endocytosis function was not impaired by the antibiotic. With regard to the evaluation of the cytotoxicity caused by gentamicin, MDCK-C11 cells showed a significant decrease in metabolic activity with 48-h exposure, which indicates metabolic stress.

As shown in Figure 2, gentamicin promoted an increase in the $\left[\mathrm{Ca}^{2+}\right]_{i}$ level. A high concentration of $\mathrm{Ca}^{2+}$ released from the endoplasmic reticulum promotes a consequent high $\mathrm{Ca}^{2+}$ uptake by mitochondria. In these organelles, high $\mathrm{Ca}^{2+}$ levels activate apoptosis pathways (8). Therefore, the reduction in the metabolic activity of MDCK-C11 cells observed after $48 \mathrm{~h}$ of exposure can be interpreted as the beginning of an apoptotic process promoted by gentamicin. Further studies are necessary to confirm a hypothetical apoptosis induced by gentamicin in MDCKC11 cells.

Scanning electron microscopy analysis showed that gentamicin promoted morphological and ultrastructural changes in MDCK-C11 cells. With longer exposure to aminoglycoside $(24 \mathrm{~h})$, cells failed to remain adhered, losing their adhesion to the extracellular matrix (ECM), possibly by modulation of the receptors that enable cell adhesion. Among several molecules related to ECM, the transmembrane glycoproteins integrins can be emphasized, which have $\alpha$ and $\beta$ domains and are membrane receptors. These biomolecules interconnect the internal cell cytoskeleton with the ECM (20). Among the ECM proteins with which integrins intersect are fibronectin, laminin, and vitronectin. This interaction is modulated via cytoplasmic proteins such as vinculin, talin, and $\alpha$-actinin, which interact with integrins and cytoskeletal proteins,

\section{References}

1. Balakumar P, Rohilla A, Thangathirupathi A. GentamicinInduced Nephrotoxicity: Do we have a promising therapeutic approach to blunt it? Pharmacoll Res 2010; 62: 179-186, doi: 10.1016/j.phrs.2010.04.004.

2. Santucci RA, Krieger JN. Gentamicin for the practicing urologist: review of efficacy single daily dosing and "switch and are involved in dynamic adhesion, invasion, migration, and proliferation (21). Syndecan is a cell surface proteoglycan, which can act as a co-receptor for growth factors and ECM proteins by increasing the affinity of these molecules to their specific receptors; it also participates in cell adhesion on focal contacts with integrins and focal adhesion kinase, connecting the ECM to the cytoskeleton. Thus, it is believed that the loss of adhesion to the substrate in MDCK-C11 cells treated for $24 \mathrm{~h}$ with gentamicin would be related to any changes in the activity of membrane proteins such as integrins and syndecan.

The dose of gentamicin used in the present study ( $0.1 \mathrm{mM}$ gentamicin sulfate) was smaller than that used in other in vitro studies. However, this dose of gentamicin was shown to alter metabolism and morphology of MDCKC11 cells. Gibbons et al. (22) showed that gentamicin induces cell death in OK cells (proximal tubular cells) at a low concentration $(50 \mu \mathrm{M})$. In addition, some studies have shown that gentamicin is able to cross the plasma membrane (via cation channels) of renal tubular cells, including MDCK. Thus, induction of cytotoxicity caused by gentamicin may possibly occur at very low doses of the antibiotic (23).

In conclusion, our results demonstrated that gentamicin was capable of promoting a significant increase in $\left[\mathrm{Ca}^{2+}\right]_{\mathrm{i}}$ levels in MDCK C11 cells, which is dependent on the presence of $\mathrm{Ca}^{2+}$ in the extracellular medium. The gentamicin-induced increase in $\left[\mathrm{Ca}^{2+}\right]_{i}$ levels was significantly higher compared to the increase caused by a CaSR agonist, gadolinium. Gentamicin altered metabolic activity and morphology of cells that resemble those of intercalated cells of the distal nephron. Intercalated cells play an important role in the acid-base balance of the organism, contributing to $\mathrm{pH}$ homeostasis by reabsorbing bicarbonate and secreting the hydrogen ion in accordance with the body's needs. The findings of the present study demonstrate, for the first time, that the toxic effect of gentamicin on intercalated cells can lead to changes in the metabolism of these cells. These changes promote cell death, which could contribute to the progression of renal failure.

\section{Acknowledgments}

The authors are grateful to Dr. Célia Regina Cavichiolo Franco for the help with ultrastructural analysis and useful suggestions, and to CAPES for financial support.

therapy". J Urol 2000; 163: 1076-1084, doi: 10.1016/S00225347(05)67697-5.

3. Quiros Y, Vicente-Vicente L, Morales Al, López-Novoa JM, López-Hernández FJ. An integrative overview on the mechanisms underlying the renal tubular cytotoxicity of gentamicin. Toxicol Sc 2011; 119: 245-256, doi: 10.1093/toxsci/kfq267. 
4. Leehey DJ, Braun BI, Tholl DA, Chung LS, Gross CA, Roback JA, et al. Can pharmacokinetic dosing decrease nephrotoxicity associated with aminoglycoside therapy? J Am Soc Nephrol 1983; 4: 81-90.

5. Xu C, Bailly-Maitre B, Reed JC. Endoplasmic reticulum stress: cell life and death decisions. J Clin Invest 2005; 115: 2656-2664, doi: 10.1172/JCl26373.

6. Moestrup SK, Cui S, Vorum H, Bregengard C, Bjorn SE, Norris K, et al. Evidence that glycoprotein 330/megalin uptake of polybasic drugs. J Clin Invest 1995; 96: 1404-1413, doi: $10.1172 / \mathrm{JCl} 118176$.

7. Ward DT, Maldonado-Pérez D, Hollins L, Riccardi D. Aminoglycosides induce acute cell signaling and chronic cell death in renal cells that express the calcium-sensing receptor. J Am Soc Nephrol 2005; 16: 1236-1244, doi: 10.1681/ ASN.2004080631.

8. Wegierski T, Steffl D, Kopp C, Tauber R, Buchholz B, Nitschke $R$, et al. TRPP2 channels regulate apoptosis through the $\mathrm{Ca}^{2+}$ concentration in the endoplasmic reticulum. Embo J 2009; 28: 490-499, doi: 10.1038/emboj.2008.307.

9. Myrdal SE, Steyger PS. TRPV1 regulators mediate gentamicin penetration of cultured kidney cells. Hear Res 2005; 204: 170-182, doi: 10.1016/j.heares.2005.02.005.

10. Karasawa T, Wang Q, Fu Y, Cohen DM, Steyger PS. TRPV4 enhances cellular uptake of aminoglycoside antibiotics. J Cell Sci 2008; 121: 2871-2879, doi: 10.1242/jcs.023705.

11. Gekle M, Wünsch $S$, Oberleithner $H$, Silbernagl $S$. Characterizarion of two MDCK cells subtypes as model system to study principal cell and intercalated cell properties. Pflügers Arch 1994; 428: 157-162, doi: 10.1007/BF0037 4853.

12. Fernandez $\mathrm{R}$, Oliveira-Souza $\mathrm{M}$, Malnic $\mathrm{G} . \mathrm{Na}^{+}$-independent proton secretion in MDCK - C11 cells. Pflugers Arch 2000; 441: 287-293, doi: $10.1007 / \mathrm{s} 004240000411$.

13. Blankenship KA, Williams JJ, Lawrence MS, McLeish KR, Dean WL, Arthur JM. The calcium-sensing receptor regulates calcium absorption in MDCK cells by inhibition of PMCA. Am J Physiol Renal Physiol 2001; 280: 815-822, doi: 10.1152/ajprenal.2001.280.5.F815.
14. Randjelovic P, Veljkovic S, Stojiljkovic N, Sokolovic D, llic I. Gentamicin nephrotoxicity in animals: current knowledge and future perspectives. EXCLI Journal 2017; 16: 388-399, doi: 10.17179/excli2017-165.

15. Borenfreund E, Puener JA. A simple quantitative procedure using monolayer cultures for cytotoxicity assays (HTD/NR-90). J Tissue Cult Meth 1985; 9: 7-9, doi: 10.1007/BF01666038.

16. Fotakis G, Timbrell JA. In vitro cytotoxicity assays: comparison of LDH, neutral red, MTT and protein assay in hepatoma cell lines following exposure to cadmium chloride. Toxicol Lett 2006; 160: 171-177, doi: 10.1016/j.toxlet.2005.07.001.

17. Mosmann T. Rapid colorimetric assay for cellular growth and survival: application to proliferation and citotoxicity assays. J Immunol Meth 1983; 65: 55-63, doi: 10.1016/0022-1759 (83)90303-4.

18. Reilly TP, Bellevue FH, Woster PM, Svensson CK. Comparison of the in vitro cytotoxicity of hydroxylamine metabolites of sulfamethoxazole and dapsone. Biochem Pharmacol 1998; 55: 803-810, doi: 10.1016/S0006-2952(97)00547-9.

19. Ward DT, Mclarnon SJ, Riccardi D. Aminoglycosides increase intracellular calcium levels and ERK activity in proximal tubular OK cells expressing the extracellular calcium-sensing receptor. J Am Soc Nephrol 2002; 13: 1481-1489, doi: 10.1097/ 01.ASN.0000015623.73739.B8.

20. Plow EF, Haas TA, Zhang L, Loftus J, Smith JW. Ligand binding to integrins. J Biol Chem 2000; 275: 21785-21788, doi: 10.1074/jbc.R000003200.

21. Woods A, Couchman JR. Integrin modulation by lateral association. J Biol Chem 2000; 275: 24233-24236, doi: 10.1074/jbc.R000001200.

22. Gibbons CE, Maldonado-Pérez D, Shah AN, Riccardi D, Ward DT. Calcium-sensing receptor antagonism or lithium treatment ameliorates aminoglycoside-induced cell death in renal epithelial cells. Biochim Biophys Acta 2008; 1782: 188-195, doi: 10.1016/j.bbadis.2008.01.003.

23. Nagai J, Takano M. Entry of aminoglycosides into renal tubular epithelial cells via endocytosis-dependent and endocytosisindependent pathways. Biochem Pharmacol 2014; 90: 331-337, doi: 10.1016/j.bcp.2014.05.018. 